\section{'Northern Treasure' and 'Northern Gem' Hybrid Ash}

\author{
Campbell G. Davidson \\ Morden Research Centre, Agriculture and Agri-Food Canada, Unit 100-101 \\ Route 100, Morden, MB, R6M 1 Y5 Canada
}

Additional index words. Fraxinus, shade tree, hardiness, ornamentals

'Northern Treasure' (Fig. 1) and 'Northern Gem' (Fig. 2) are two new hybrid ash (Fraxinus nigra Marsh. X F. mandshurica Rupr.) cultivars being released from the AAFCMorden Research Centre landscape plant breeding program that are well suited to cold regions of the northern Great Plains and prairie Canada. They combine the hardiness of the female parent (Fraxinus nigra) with the growth rate and form of the male parent $(F$. mandshurica).

\section{Origin}

'Northern Treasure' and 'Northern Gem' have similar parentage: Fraxinus nigra $\times$ F. mandshurica. Crossing was done in the field in the early 1970s, when Dr. Bill Cumming was leader of the ornamentals program at Morden. The hybridization resulted in a population of seedlings, of which several demonstrated morphological characteristics intermediate between the two parental species which were identified by Dr. Wilbert Ronald. The final selection was completed by the author. This is the first report known to the author of cultivar releases as a result of successful hybridization between these two species. The female tree was obtained originally from a native population (eastern Manitoba) of black ash while the pollen parent was originally obtained from the U.S. Dept. of Agriculture Center at Beltsville, Md., in 1959. The seedlings were lined out in a nursery field and observed for over 10 years. Final selections were made in 1989. Plants have been in regional trials in western Canada for several years with no winter injury being noted (Davidson et al., 1994a, 1994b).

\section{Description}

'Northern Treasure' has an upright form with an acute branching habit. Mean branch divergence angle from the parent shoot is $50.7^{\circ}$. Mean numbers of branches per parent shoot average 4.7 on mid-crown sampled shoots. A dominant centre axis is more common in this plant, resulting in an upright form.

\footnotetext{
Received for publication 6 Oct. 1997. Accepted for publication 24 Apr. 1998. I would like to acknowledge the technical assistance of R.J. Enns and S.M Gobin and numerous summer students. Without their assistance progress would be difficult. The cost of publishing this paper was defrayed in part by the payment of page charges. Under postal regulations, this paper therefore must be hereby marked advertisement solely to indicate this fact.
}

Pinnately compound leaves are shiny yellowgreen in the summer (147A upper surface; 137C lower surface, RHS). All color distinctions adhere to the Royal Horticultural Society color charts (1986). Numbers of leaflets per leaf vary from 9 to 11 , with 11 leaflets predominating. Leaves average $28.6 \mathrm{~cm}$ in width and $32.9 \mathrm{~cm}$ in length overall. Leaflet length and width average $16.1 \mathrm{~cm}$ and $5.6 \mathrm{~cm}$, respectively. Leaflet margins are serrate. Fall leaf colour is pale yellow-orange (16C upper and lower surface).

'Northern Gem' is an oval to round-shaped tree with a crown that is almost as wide as tall when open grown. Mean branch divergence angle from the parent shoot is $69^{\circ}$. Mean numbers of branches per parent shoot average 5.3 on mid-crown sampled shoots. Pinnately compound leaves are dull green in summer (137A upper surface; 147B lower surface). Numbers of leaflets per leaf vary from 9 to 11 . Leaves average $29.5 \mathrm{~cm}$ in width and $35.6 \mathrm{~cm}$ in length overall. Leaflet length and width average $15.7 \mathrm{~cm}$ and $5.2 \mathrm{~cm}$, respectively. Leaflet margins are serrate. Fall leaf color is pale orange-yellow (20C upper surface; 162C lower surface).

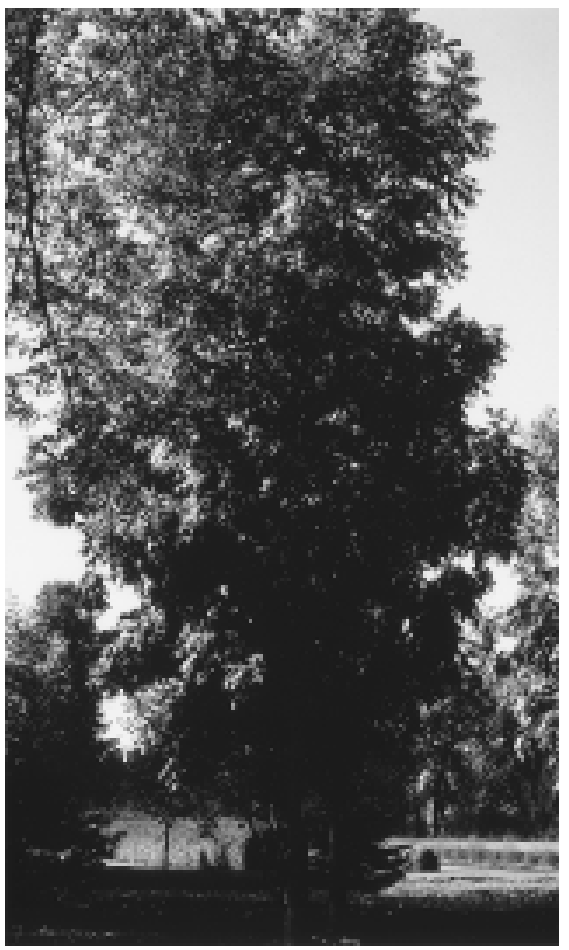

Fig. 1. 'Northern Treasure' hybrid ash
Both trees are vigorous. The length of midcrown samples of terminal shoots formed in 1994 and 1995 averaged $32.0 \mathrm{~cm}$ and $30.5 \mathrm{~cm}$ for 'Northern Treasure' and $30 \mathrm{~cm}$ and 25.6 $\mathrm{cm}$ for 'Northern Gem' (Table 1). The differences in plant form are attributed to growth rate, numbers of branches, and divergence angles of the branches. 'Northern Gem' has greater numbers of lateral branches developing at greater divergence angles from the parent shoot axis. Additional architectural, growth, and descriptive data are presented in Table 1. In controlled laboratory freezing assessments, both cultivars had excellent acclimation rates and low temperature tolerance. Throughout fall and winter sampling times, LT50s were intermediate between the two parents. There was limited tissue damage down to $-20^{\circ} \mathrm{C}$ in October, $-40{ }^{\circ} \mathrm{C}$ in November and $-50^{\circ} \mathrm{C}$ in December.

'Northern Treasure' and 'Northern Gem' often are perfect-flowered, with male and female flowers born in the same floral structure (Fig. 3). Although most Fraxinus species are dioecious, $F$. nigra reportedly is often perfectflowered (Hosie, 1969). However, no viable seed from the new hybrids has been collected nor seedlings established to date. Seed production is not viewed as a detriment due to relatively low quantities produced.

\section{Propagation and uses}

'Northern Treasure' and 'Northern Gem' can be propagated by budding or grafting onto $F$. pennsylvanica Marsh. or $F$. nigra rootstock. Early growth in nursery environments is very rapid, often exceeding $2 \mathrm{~m}$ in height by the end of the second year.

Both cultivars should be widely adapted to colder regions of North America for use as shade or street trees. Plants should be hardy to zone 2b (Ouellet and Sherk, 1967; Sherk and Buckley, 1968). 'Northern Treasure', by virtue of its more upright form, should be well suited as a street or boulevard tree in urban

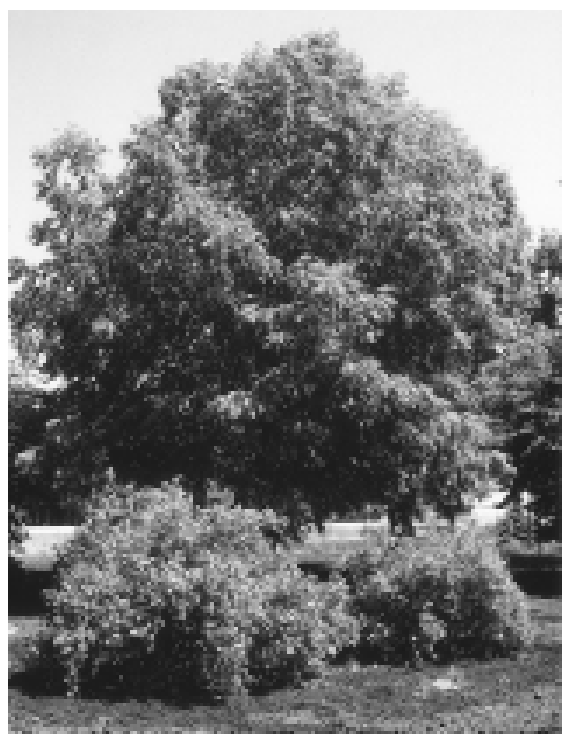

Fig. 2. 'Northern Gem' hybrid ash. 
Table 1. Architectural and growth-related measurements for 'Northern Gem' and 'Northern Treasure' hybrid ash. All measurements were taken on shoots sampled from the mid-crown region of three 15-yearold trees.

\begin{tabular}{|c|c|c|}
\hline \multirow[b]{2}{*}{ Characteristics } & \multicolumn{2}{|c|}{ Cultivar } \\
\hline & Northern Treasure & Northern Gem \\
\hline \multicolumn{3}{|l|}{ Mean shoot lengths $(\mathrm{cm})$} \\
\hline 1995 terminal & 9.4 & 25.3 \\
\hline 1995 lateral & 34.8 & 145.7 \\
\hline \multicolumn{3}{|l|}{ Mean mid-shoot diameters (mm) } \\
\hline 1995 terminal & 6.9 & 6.4 \\
\hline 1995 lateral & 7.1 & 5 \\
\hline \multicolumn{3}{|l|}{ Mean terminal bud } \\
\hline Length (mm) & 5.6 & 4.4 \\
\hline Width $(\mathrm{mm})$ & 5.4 & 4.6 \\
\hline Color (RHS) & $200 \mathrm{~A}$ & $200 \mathrm{~A}$ \\
\hline \multicolumn{3}{|l|}{ Mean lateral bud } \\
\hline Length $(\mathrm{mm})$ & 2.6 & 1.9 \\
\hline Width (mm) & 4 & 2.8 \\
\hline Color (RHS) & $200 \mathrm{~A}$ & $200 \mathrm{~A}$ \\
\hline \multicolumn{3}{|l|}{ Bark coloration (RHS) } \\
\hline Current season & $152 \mathrm{~A}$ & 199A \\
\hline Previous season & 199B & $199 \mathrm{C}$ \\
\hline Mean tree height (m) & 12.2 & 11.8 \\
\hline Mean canopy width $(\mathrm{cm})$ & 590 & 870 \\
\hline Main stem circumference ${ }^{z}(\mathrm{~cm})$ & 75 & 98 \\
\hline
\end{tabular}

${ }^{2}$ Stem circumference was measured at breast height.

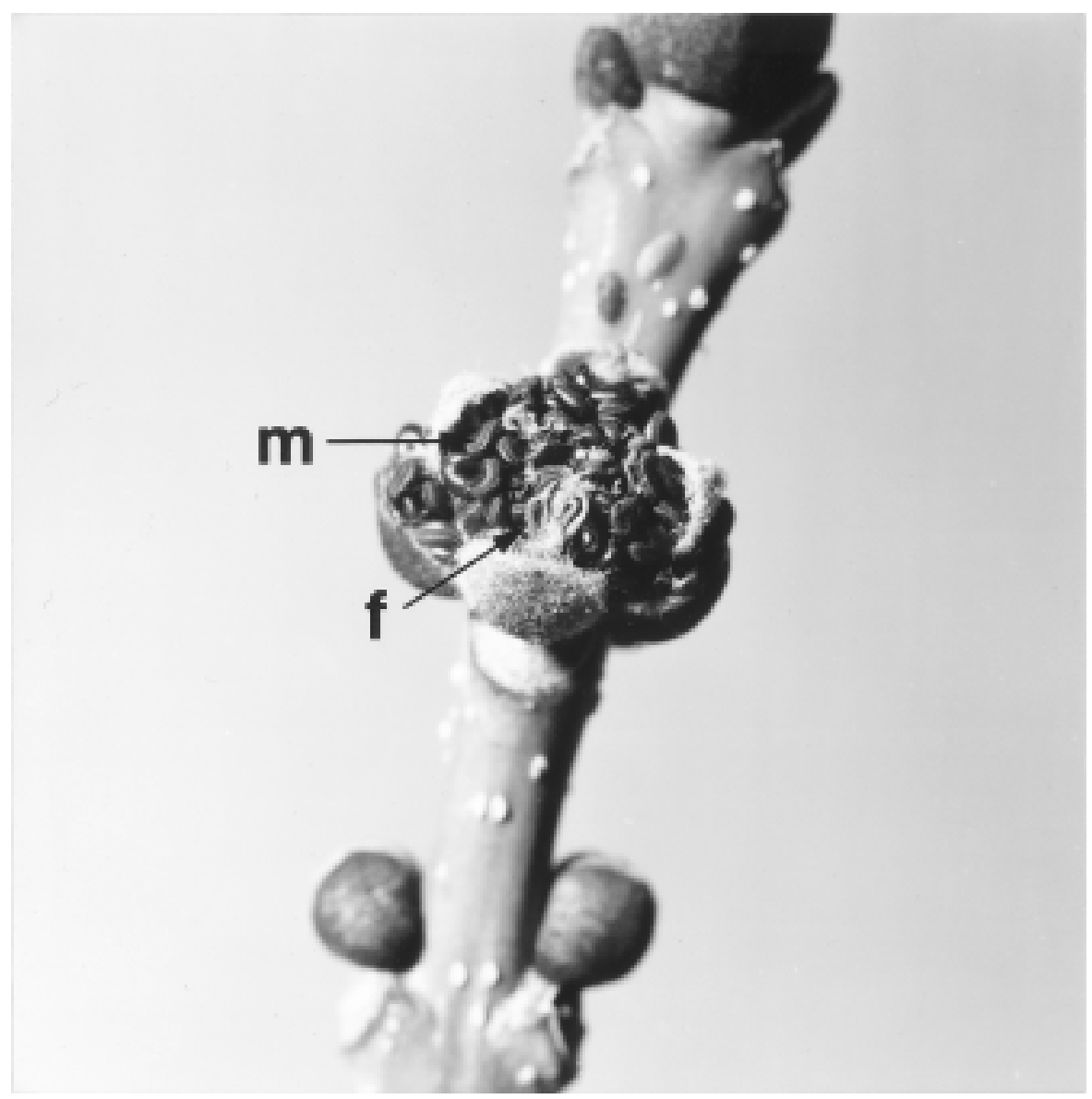

Fig. 3. Typical inflorescence of hybrid ash. Arrows indicate male (m) and female (f) parts. situations. 'Northern Gem', with the broader crown, should make an excellent shade tree. Both trees over the 15-year evaluation process have not been attacked by flower bud gall insects. Black ash is susceptible to the insect, while the male parent, Manchurian ash, appears to be resistant.

\section{Availability}

'Northern Treasure' and 'Northern Gem' ash are registered with the Canadian Ornamental Plant Foundation (COPF), P.O. Box 21083, North Bay, ON, P1B 7N8, Canada, and with the Arnold Arboretum, Jamaica Plains, Mass. Propagation material is available to COPF members in Canada by contacting the author. The COPF acts as Agriculture and Agri-Food Canada's royalty collection agent and will be seeking Plant Breeder Rights protection for the new cultivars in Canada. Research material is available on a limited basis after signing a nonpropagation agreement. In the United States, Bailey Nurseries, St. Paul, Minn., have exclusive propagation and distribution rights to these cultivars and a patent application has been filed.

\section{Literature Cited}

Davidson, C.G., R. Enns, and S. Gobin. 1994a. Prairie regional trials for woody ornamentals 1959-1993. Agriculture and Agri-Food Canada, Morden Research Centre, Misc. Publication.

Davidson, C.G., R. Enns, and S. Gobin. 1994b. Landscape plants at the Morden Arboretum. Agriculture and Agri-Food Canada, Morden Research Centre, Misc. Publication.

Hosie, R.C. 1969. Native trees of Canada. Dept. of Environment, Can. For. Serv., Montreal Lithographing, Montreal, Que.

Ouellet, C.E. and L.C. Sherk. 1967. Woody ornamental plant zonation. III. Suitability map for probable winter survival of ornamental trees and shrubs. Can. J. Plant Sci. 47:3513-3518.

Royal Horticultural Society. 1986. Royal Horticultural Society Colour Chart. London.

Sherk, L.C. and A.R. Buckley. 1968. Ornamental shrubs for Canada. Can. Dept. Agri. Pub.\#1286, Research Branch, Ottawa, Canada. 